Article

\title{
Synthesis, Structure and 1,3-Butadiene Polymerization Behavior of Vanadium(III) Phosphine Complexes
}

\author{
Giuseppe Leone 1 (D), Giorgia Zanchin ${ }^{1,2}$, Ivana Pierro ${ }^{1,3}$, Anna Sommazzi 4 (D), \\ Alessandra Forni ${ }^{5}$ and Giovanni Ricci ${ }^{1, *}$ (D) \\ 1 CNR, Istituto per lo Studio delle Macromolecole (ISMAC), via A. Corti 12, I-20133 Milano, Italy; \\ giuseppe.leone@ismac.cnr.it (G.L.); giorgia.zanchin@ismac.cnr.it (G.Z.); ivana.pierro@ismac.cnr.it (I.P.) \\ 2 Dipartimento di Chimica, Università degli Studi di Milano, via C. Golgi 19, I-20133 Milano, Italy \\ 3 Dipartimento di Scienze Chimiche, Università degli Studi di Napoli Federico II, Complesso Monte S. Angelo, \\ Via Cintia, I-80126 Napoli, Italy \\ 4 Versalis S.p.A., Istituto Eni Donegani, via G. Fauser 4, I-28100 Novara, Italy; \\ anna.sommazzi@versalis.eni.com \\ 5 CNR, Istituto di Scienze e Tecnologie Molecolari (ISTM), Università degli Studi di Milano, via C. Golgi 19, \\ I-20133 Milano, Italy; alessandra.forni@istm.cnr.it \\ * Correspondence: giovanni.ricci@ismac.cnr.it; Tel.: +39-02-2369-9376
}

Received: 9 November 2017; Accepted: 25 November 2017; Published: 28 November 2017

\begin{abstract}
A series of vanadium(III) complexes bearing monodentate tertiary phosphine ligands of the type $\mathrm{VCl}_{3}\left(\mathrm{PR}_{n} \mathrm{Ph}_{3-n}\right)_{2}\left(n=0(\mathbf{1 a}) ; n=1\right.$ and $\mathrm{R}=\mathrm{Me}(\mathbf{1 b}), \mathrm{Et}(\mathbf{1} \mathbf{c}),{ }^{i} \operatorname{Pr}(\mathbf{1 d}), \mathrm{Cy}(\mathbf{1 e}) ; n=2$ and $\mathrm{R}=\mathrm{Me}(\mathbf{1 f})$, Et (1g), Cy (1h)), and $\mathrm{VCl}_{3}\left(\mathrm{PR}_{3}\right)_{2}\left(\mathrm{R}=\mathrm{Cyp}(\mathbf{2 a}), \mathrm{Cy}(\mathbf{2 b}),{ }^{n} \operatorname{Pr}(\mathbf{2 c}),{ }^{t} \mathrm{Bu}(\mathbf{2 d})\right)$ were synthesized and characterized. In the case of $\mathbf{1 c}, \mathbf{1} \mathbf{g}$ and $\mathbf{2 a}$ single crystals were also obtained and their molecular structures were determined. All the complexes were used, in combination with methylaluminoxane (sMAO) or $\mathrm{AlMe}_{3}$-free MAO (dMAO), for the polymerization of 1,3-butadiene, exhibiting rather good activity and giving polymers with different microstructure depending on the nature of the phosphine ligand and the type of co-catalyst employed.
\end{abstract}

Keywords: vanadium phosphine complexes; X-ray structure; 1,3-butadiene polymerization; poly(1,3-butadiene)

\section{Introduction}

The polymerization of 1,3-butadiene plays an important role in the field of stereospecific polymerization, and it is of great interest for both the academic and industrial world. Lanthanides (e.g., $\mathrm{Nd}, \mathrm{Pr}$ ) and transition metals (e.g., Ti, V, Cr, Fe, Co, Ni) compounds in combination with suitable alkylating agents (e.g., $\mathrm{AlEt}_{3}$, $\mathrm{AlEt}_{2} \mathrm{Cl}, \mathrm{MAO}$ ) were successfully used for the polymerization of 1,3-butadiene, affording polymers with different structure (i.e., trans-1,4, cis-1,4, isotactic 1,2, syndiotactic 1,2 and mixed cis-1,4/1,2 structure with variable 1,2 content) depending on the catalyst nature [1-3].

In particular, vanadium based catalysts are mainly known for their ability to give highly trans-1,4 poly(1,3-butadiene) [1]. A crystalline, highly stereoregular trans-1,4 poly(1,3-butadiene) (trans-1,4 $\geq 99 \%$ ) with high molecular weight and melting point of about $130{ }^{\circ} \mathrm{C}$ was synthesized with the heterogeneous systems obtained by combining a vanadium chloride (e.g., $\mathrm{VCl}_{3}, \mathrm{VCl}_{4}$ ) with an aluminum alkyl (e.g., $\mathrm{AlEt}_{3}, \mathrm{AlEt}_{2} \mathrm{Cl}$ ) [4]. A highly trans-1,4 poly(1,3-butadiene), but with lower molecular weight and melting point, was also obtained with the soluble catalytic systems $\mathrm{VCl}_{3} \cdot 3 \mathrm{THF} / \mathrm{AlEt}_{2} \mathrm{Cl}$ [5], $\mathrm{V}(\mathrm{acac})_{3} / \mathrm{AlEt}_{2} \mathrm{Cl}$ (acac = acetylacetonate) [6], and $\mathrm{V}(\mathrm{acac})_{3} / \mathrm{MAO}[7,8]$. trans-1,4 Poly(1,3-butadiene)s were also obtained with catalysts based on vanadium(III) complexes 
bearing a bis(imino)pyridyl ligand (i.e., $\mathrm{VCl}_{3}\left\{2\right.$,6-bis $\left.\left.\left[\left(2,6-i \mathrm{Pr}_{2} \mathrm{C}_{6} \mathrm{H}_{3}\right) \mathrm{NC}(\mathrm{Me})\right]_{2}\left(\mathrm{C}_{5} \mathrm{H}_{3} \mathrm{~N}\right)\right\}\right)$; the activity of these systems was, however, rather low [9]. Some vanadium based catalysts were also able to give 1,2 syndiotactic and predominantly cis-1,4 poly(1,3-butadiene)s. $\mathrm{V}(\mathrm{acac})_{3}$, in combination with $\mathrm{AlEt}_{3}$, was found to be an efficient catalyst for the synthesis of syndiotactic 1,2 poly(butadiene)s [10]; $\mathrm{V}\left(\eta^{5}-\mathrm{C}_{5} \mathrm{H}_{5}\right)_{2} \mathrm{Cl}$ and $\mathrm{V}\left(\eta^{5}-\mathrm{C}_{5} \mathrm{H}_{4} \mathrm{Me}\right)\left(\mathrm{PEt}_{3}\right)_{2} \mathrm{Cl}_{2}$, in combination with $\mathrm{MAO}$, gave polymers with a predominantly cis-1,4 structure (cis content of about $85 \%$ ) with a quite good activity [11-13]. Essentially cis-1,4 poly(1,3-butadiene)s were also obtained by using some amino-functionalized cyclopentadienyl vanadium(III) complexes (e.g., $\left.\mathrm{V}\left\{\eta^{5}-\mathrm{C}_{5} \mathrm{H}_{4} \mathrm{CH}\left(\mathrm{CH}_{2}\right)_{4} \mathrm{NMe}\right\}_{2} \mathrm{Cl}, \mathrm{V}\left\{\eta^{5}-\mathrm{C}_{5} \mathrm{H}_{4}\left(\mathrm{CH}_{2}\right)_{2} \mathrm{~N}\left(\mathrm{CH}_{2}\right)_{5}\right\}_{2} \mathrm{Cl}\right)$ [14].

In recent years, several studies on the use of various transition metal phosphine complexes for the polymerization of 1,3-dienes have been reported [15-24]. Catalysts obtained by combining various phosphine complexes of chromium(II) [15-17] and cobalt(II) [18-20] with MAO were found to be extremely active and selective in the polymerization of 1,3-dienes: highly stereoregular polymers having different structure were obtained depending on the type of metal, the type of ligand and the monomer polymerized [21-24]. As far as we know, up to now, only few examples of vanadium(III) phosphine complexes were reported in the literature [25-31], and only some of them have been used for the polymerization of 1,3-butadiene [31].

In this paper, we report on the synthesis and characterization of several vanadium(III) complexes of the type $\mathrm{VCl}_{3}\left(\mathrm{PR}_{\mathrm{n}} \mathrm{Ph}_{3-\mathrm{n}}\right)_{2}(\mathrm{n}=0$ (1) $) ; \mathrm{n}=1$ and $\mathrm{R}=\mathrm{Me}(\mathbf{1} \mathbf{b}), \mathrm{Et}(\mathbf{1} \mathbf{c}),{ }^{i} \operatorname{Pr}(\mathbf{1 d}), \mathrm{Cy}(\mathbf{1 e}) ; \mathrm{n}=2$ and $\mathrm{R}=\mathrm{Me}(\mathbf{1} \mathbf{f}), \mathrm{Et}(\mathbf{1} \mathbf{g})$, $\mathrm{Cy}(\mathbf{1 h})$, and $\mathrm{VCl}_{3}\left(\mathrm{PR}_{3}\right)_{2}\left(\mathrm{R}=\right.$ cyclopentyl $(\mathrm{Cyp}, \mathbf{2 a}), \mathrm{Cy}(\mathbf{2 b}),{ }^{n} \operatorname{Pr}(\mathbf{2 c}),{ }^{t} \mathrm{Bu}(\mathbf{2 d})$, including single-crystal X-ray structural determination of $\mathbf{1 c}, \mathbf{1 g}$ and $\mathbf{2 a}$. A preliminary study investigating the catalytic behavior of these novel complexes in the polymerization of 1,3-butadiene is presented.

\section{Results and Discussion}

The study of phosphine complexes of transition metal halides is an important topic and includes different compounds depending on the metal oxidation state and its position in the periodic table. Toward the left side (i.e., Group 4 and 5) and with oxidation states of III and IV, the phosphine-metal bonds tend to be relatively long, weak and labile, and they have little if any $\pi$ character [32], even if there are examples for which bond lengths do not correlate with their expected bond orders, as in some titanocenes phosphines adducts [33].

Among the metal-phosphine complexes reported, our interest was in preparing vanadium(III) complexes. Complexes of vanadium(III) with tertiary phosphines were prepared from $\mathrm{VCl}_{3}$ or $\mathrm{VCl}_{3}$.3THF. It has been reported that $\mathrm{PPh}_{3}$ and $\mathrm{PCy}_{3}$ reacted with $\mathrm{VCl}_{3}$ to give dimers, i.e., $\left[\mathrm{VCl}_{3}\left(\mathrm{PR}_{3}\right)\right]_{2}$ [29]. Mononuclear complexes with a coordination number of 5 were instead obtained by reacting $\mathrm{VCl}_{3}$. 3THF with $\mathrm{PMePh}_{2}, \mathrm{PEt}_{2} \mathrm{Ph}$, and $\mathrm{PR}_{3}(\mathrm{R}=\mathrm{Me}, \mathrm{Et})$; with a coordination number of 6 [i.e., $\mathrm{VCl}_{3}\left(\mathrm{P}^{n} \mathrm{Pr}\right)_{3}$ and $\mathrm{VCl}_{3}\left(\mathrm{PR}_{2} \mathrm{Ph}\right)_{3}\left(\mathrm{R}=\mathrm{Me},{ }^{n} \mathrm{Pr}\right)$ ] by reacting $\mathrm{VCl}_{3} \cdot 3 \mathrm{THF}$ with $\mathrm{P}^{n} \mathrm{Pr}_{3}, \mathrm{PMe}_{2} \mathrm{Ph}$ and $\mathrm{P}^{n} \mathrm{Pr}_{2} \mathrm{Ph}[26,28]$. With other aliphatic phosphines, only intractable oils were obtained likely due to a reduction-hydrolysis process occurring during the reaction and subsequent workup [32].

In this work, we explore the chemical reactivity of $\mathrm{VCl}_{3}$.3THF versus tertiary phosphine by extending the spectrum of phosphine ligands; The synthesis of vanadium complexes with $\mathrm{PR}_{\mathrm{n}} \mathrm{Ph}_{3-\mathrm{n}}$ ( $\left.\mathrm{n}=0,1,2 ; \mathrm{R}=\mathrm{Me}, \mathrm{Et},{ }^{i} \mathrm{Pr}, \mathrm{Cy}\right)$ and $\mathrm{PR}_{3}\left(\mathrm{R}=\mathrm{Cyp}, \mathrm{Cy},{ }^{n} \mathrm{Pr},{ }^{t} \mathrm{Bu}\right)$ is reported, including single-crystal X-ray structural determination for $\mathrm{VCl}_{3}\left(\mathrm{PEtPh}_{2}\right)_{2}(\mathbf{1} \mathbf{c}), \mathrm{VCl}_{3}\left(\mathrm{PEt}_{2} \mathrm{Ph}\right)_{2}(\mathbf{1 g})$ and $\mathrm{VCl}_{3}\left(\mathrm{PCyp}_{3}\right)_{2}(\mathbf{2 a})$.

\subsection{Synthesis and Structure of V(III)-Phosphine Complexes}

Complexes of type $\mathrm{VCl}_{3}\left(\mathrm{PR}_{\mathrm{n}} \mathrm{Ph}_{3-\mathrm{n}}\right)_{2}(\mathrm{n}=0 ; \mathrm{n}=1, \mathrm{R}=\mathrm{Me}, \mathrm{Et}, \mathrm{Cy} ; \mathrm{n}=2, \mathrm{R}=\mathrm{Me})$ and $\mathrm{VCl}_{3}\left(\mathrm{PR}_{3}\right)_{2}$ $(\mathrm{R}=\mathrm{Cyp}, \mathrm{Cy})$ were obtained in good yield as microcrystalline solids by addition of the phosphine to a $\mathrm{VCl}_{3} \cdot 3 \mathrm{THF}$ suspension in toluene ( $\mathrm{P} / \mathrm{V}=4: 1$ mole ratio). Single crystals, suitable for $\mathrm{X}$-ray structure determination, were obtained for $\mathbf{1} \mathbf{b}$, whose structure was previously reported $[25,27,30]$, $\mathbf{1 c}$ and $\mathbf{2 a}$ from cold pentane. In contrast, the reaction in toluene with phosphine of type $\mathrm{PR}_{\mathrm{n}} \mathrm{Ph}_{3-\mathrm{n}}$ $\left(\mathrm{n}=2, \mathrm{R}=\mathrm{Et},{ }^{t} \mathrm{Bu}, \mathrm{Cy}\right)$ and $\mathrm{PR}_{3}\left(\mathrm{R}={ }^{n} \mathrm{Pr},{ }^{t} \mathrm{Bu}\right)$ gave an oily product, difficult to recover. Dusty solids were instead successfully obtained by performing the reaction in THF and adding the ligand dropwise; 
single crystals, suitable for X-ray structure determination, were obtained only for $\mathbf{1 g}$. Due to their low stability in air, all crystals required low temperature to minimize crystal decay during X-ray data collection (130 K for $\mathbf{1 b}$ [30], and $\mathbf{1 c}, 150 \mathrm{~K}$ for $\mathbf{1 g}$ and $100 \mathrm{~K}$ for $\mathbf{2 a}$, according to their different stability). A list of selected bond distances and angles for $\mathbf{1 b}$ [30], 1c, $\mathbf{1 g}$ and $\mathbf{2 a}$ as obtained by X-ray investigation is reported in Table 1 , while a view of the molecular structures of $\mathbf{1 c}, \mathbf{1} \mathbf{g}$ and $\mathbf{2 a}$ is reported in Figure 1. DFT gas-phase geometry optimizations, starting from the experimental structures, have been performed on the four complexes in order to discern the effect of crystal packing, if any, on the experimental geometries. Two exchange-correlation functionals have been used to assess the reliability of the theoretical investigation: M06 [34], due to its specific parametrization on organometallic complexes, and B3LYP [35-37], by far the most used functional for geometry optimizations. The results are reported as well in Table 1. At a glance, M06 showed much better performance with respect to B3LYP as far as bond lengths are concerned, while bond angles are in all cases quite similar.

Table 1. Selected X-ray (first row) and Computed (UM06/6-311g(d) and UB3LYP/6-311g(d), second and third row, respectively, in italics) Bond Lengths $(\AA)$ and Angles $\left(^{\circ}\right)$ for $\mathbf{1 b}[30], 1 \mathbf{c}, \mathbf{1 g}$ and $\mathbf{2 a}{ }^{a}$.

\begin{tabular}{|c|c|c|c|c|}
\hline $\begin{array}{l}\text { Bond Lengths } \\
\text { and Angle }\end{array}$ & $\begin{array}{c}\mathrm{VCl}_{3}\left(\mathrm{PMePh}_{2}\right)_{2} \\
\text { (1b) }\end{array}$ & $\begin{array}{c}\mathrm{VCl}_{3}\left(\mathrm{PEtPh}_{2}\right)_{2} \\
\text { (1c) }\end{array}$ & $\begin{array}{c}\mathrm{VCl}_{3}\left(\mathrm{PEt}_{2} \mathrm{Ph}\right)_{2} \\
(1 \mathrm{~g})\end{array}$ & $\begin{array}{c}\mathrm{VCl}_{3}\left(\mathrm{PCyp}_{3}\right)_{2} \\
\text { (2a) }\end{array}$ \\
\hline \multirow{3}{*}{$\mathrm{V}-\mathrm{Cl}$} & $2.2287(8)$ & $2.2408(6)$ & $2.246(10)$ & $2.247(10)$ \\
\hline & 2.243 & 2.243 & 2.245 & 2.251 \\
\hline & 2.255 & 2.255 & 2.258 & 2.261 \\
\hline \multirow{3}{*}{$\mathrm{V}-\mathrm{P}$} & $2.5280(6)$ & $2.5465(6)$ & $2.5196(11)$ & $2.5696(10)$ \\
\hline & 2.537 & 2.551 & 2.549 & 2.587 \\
\hline & 2.607 & 2.617 & 2.613 & 2.660 \\
\hline \multirow{3}{*}{$\mathrm{P}-\mathrm{C}_{\mathrm{ar}}$} & $1.820(2)$ & 1.8251(19) & $1.813(4)$ & - \\
\hline & 1.825 & 1.826 & 1.828 & - \\
\hline & 1.840 & 1.841 & 1.841 & - \\
\hline \multirow{3}{*}{$\mathrm{P}-\mathrm{C}_{\text {aliph }}$} & $1.822(2)$ & $1.8332(19)$ & $1.828(4)$ & $1.847(3)$ \\
\hline & 1.828 & 1.844 & 1.842 & 1.850 \\
\hline & 1.843 & 1.861 & 1.860 & 1.869 \\
\hline \multirow{3}{*}{$\mathrm{Cl}-\mathrm{V}-\mathrm{Cl}$} & 119.98(3) & $119.99(2)$ & $114.6(2)$ & $120.00(4)$ \\
\hline & 120.00 & 120.00 & 119.98 & 120.00 \\
\hline & 120.00 & 120.00 & 119.98 & 120.00 \\
\hline \multirow{3}{*}{$\mathrm{P}-\mathrm{V}-\mathrm{P}$} & $169.02(2)$ & $177.87(2)$ & $167.24(4)$ & $170.48(3)$ \\
\hline & 174.74 & 177.79 & 174.06 & 174.66 \\
\hline & 175.06 & 177.78 & 174.25 & 174.77 \\
\hline \multirow{3}{*}{$\mathrm{C}_{\mathrm{ar}}-\mathrm{P}-\mathrm{C}_{\mathrm{ar}}$} & $103.73(10)$ & $103.85(8)$ & - & - \\
\hline & 103.64 & 104.39 & - & - \\
\hline & 103.74 & 104.29 & - & - \\
\hline \multirow{3}{*}{$\mathrm{C}_{\mathrm{ar}}-\mathrm{P}-\mathrm{C}_{\mathrm{aliph}}$} & $105.20(11)$ & $105.42(9)$ & 105.1(2) & - \\
\hline & 104.03 & 104.31 & 104.20 & - \\
\hline & 104.09 & 104.53 & 104.17 & - \\
\hline \multirow{3}{*}{$\mathrm{C}_{\text {aliph }}-\mathrm{P}-\mathrm{C}_{\text {aliph }}$} & - & - & 103.7(2) & $105.5(2)$ \\
\hline & - & - & 102.79 & 104.09 \\
\hline & - & - & 102.87 & 104.99 \\
\hline
\end{tabular}

${ }^{a}$ Each reported value was obtained as weighted average on all the corresponding parameters present in the structure.

More precisely, both functionals provide similar trends in the geometrical parameters along the series of complexes, generally in agreement with the experimental ones. M06, however, reproduces bond lengths within $0.015 \AA$, with the only exception of V-P distances which show a maximum discrepancy of $0.029 \AA$. B3LYP overestimates bond lengths by up to $0.032 \AA$, excepted for the V-P bonds for which the maximum deviation grows up to $0.093 \AA$. In the following we therefore rely 
only on the M06 optimized geometry. The complexes adopt slightly distorted trigonal-bipyramidal geometry, where the main distortion comes from the deviation (by up to $13^{\circ}$ ) of the P-V-P angles from $180^{\circ}$. As previously discussed [30], such a deviation is mainly due to crystal packing forces (essentially $\mathrm{C}-\mathrm{H} \cdots \mathrm{Cl}[38], \mathrm{C}-\mathrm{H} \cdots \pi$ and $\pi-\pi$ intermolecular interactions, the latter two arising in structures where phenylphosphines are present), as denoted by the more regular conformation as obtained by gas-phase calculations, which provide a maximum $6^{\circ}$ deviation from a P-V-P straight angle. As a general observation, the V-P bond lengths, ranging on average from 2.520(1) to $2.570(1) \AA$ ( 2.537 to $2.587 \AA$ from UM06 calculations) in the compounds here investigated, appear to be much longer than the Mt-P $\left(\mathrm{Mt}=\right.$ metal) ones as found in tetrahedral $\mathrm{MtCl}_{2}\left(\mathrm{PR}_{\mathrm{n}} \mathrm{Ph}_{3-\mathrm{n}}\right)_{2}$ complexes, suggesting weaker bonds with scarce or null $\pi$-character for the vanadium complexes. For example, in the extended series of $\mathrm{CoCl}_{2}\left(\mathrm{PR}_{n} \mathrm{Ph}_{3-n}\right)_{2}$ complexes previously reported by some of us [18-20,39], the longest Co-P bond distance was found to be 2.437(6) $\AA$ for the more sterically hindered $\mathrm{CoCl}_{2}\left(\mathrm{PCy}_{3}\right)_{2}$ complex [19], well below the V-P shortest distance here reported. Along the series of $\mathbf{1 b}, \mathbf{1 c}, \mathbf{1 g}$ and $\mathbf{2 a}$ complexes, the trend in the V-P and, in a lesser extent, the $\mathrm{V}-\mathrm{Cl}$ average bond lengths generally follows the combined effect of the bulkiness of the phosphine ligand and its $\pi$-character. In fact, they increase with either increasing the hindrance of the phosphine and/or decreasing the $\pi$-character of the phosphine substituents. For example, going from $\mathbf{1} \mathbf{b}$ to $\mathbf{1}$, the bulkier ethyl compared to the methyl group implies an increase in the average V-P distance, $\Delta r(\mathrm{~V}-\mathrm{P})$, equal to $0.018(1) \AA$ ( $0.014 \AA$ from theory). Comparing $\mathbf{1 b}, \mathbf{1} \mathbf{c}$ and $\mathbf{1 g}$ with $\mathbf{2 a}$, we observe a definite increase $\Delta \mathrm{r}(\mathrm{V}-\mathrm{P})=0.042(1), 0.023(1)$ and $0.050(1) \AA$, respectively $(0.050,0.036$ and $0.038 \AA$ from theory), due to both the large hindrance of the cyclopentyl group and the absence of any $\pi$-electron group in the phosphine. Interestingly, replacement of one phenyl by an ethyl group (compare 1c with 1g), implying conflicting effects (reduced hindrance together with reduced $\pi$-character of the phosphine) leads to V-P shortening, $\Delta r(\mathrm{~V}-\mathrm{P})=-0.027(1)$, suggesting a dominance of the steric over the electronic effect. However, this result should be also ascribed to crystal packing forces because gas-phase calculations provide only minor contraction, $\Delta \mathrm{r}(\mathrm{V}-\mathrm{P})=-0.002 \AA$.
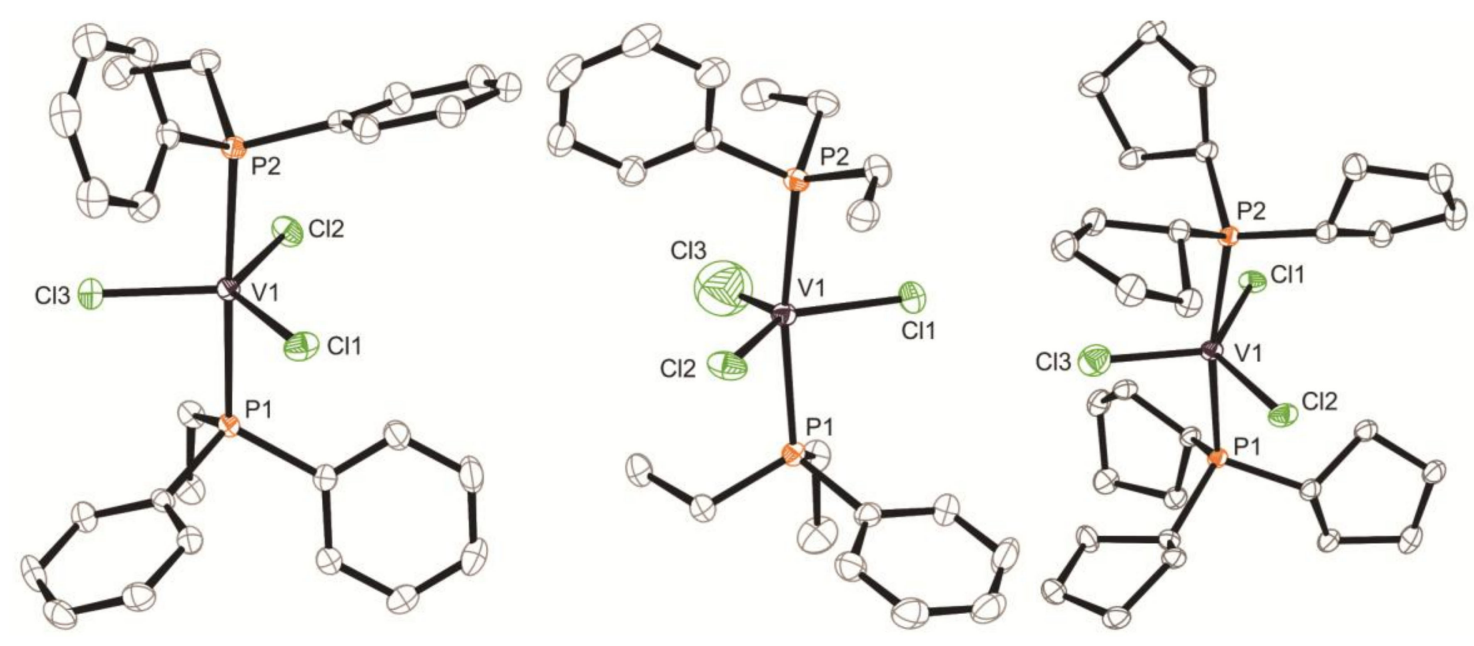

Figure 1. Molecular structures of $\mathrm{VCl}_{3}\left(\mathrm{PEtPh}_{2}\right)_{2}(\mathbf{1 c})(\mathbf{l e f t}), \mathrm{VCl}_{3}\left(\mathrm{PEt}_{2} \mathrm{Ph}\right)_{2}(\mathbf{1 g})$ (center) and $\mathrm{VCl}_{3}\left(\mathrm{PCyp}_{3}\right)_{2}$ (2a) (right) with thermal ellipsoids drawn at $50 \%$ probability level. Hydrogen atoms omitted for clarity.

Considering the $\mathrm{P}-\mathrm{C}$ bond lengths involving the aromatic carbon atoms, $\mathrm{P}-\mathrm{C}_{\mathrm{ar}}$, they are approximately constant within the experimental error, while those involving the aliphatic carbon atoms, $\mathrm{P}-\mathrm{C}_{\text {aliph}}$, follow the same trend as observed for the V-P bonds, though with a lower variability. Comparing $\mathbf{1 b}, \mathbf{1 c}$ and $\mathbf{1 g}$ with 2a, we observe in fact an increase $\Delta r\left(\mathrm{P}-\mathrm{C}_{\text {aliph }}\right)=0.025(3), 0.014(3)$ and $0.019(4) \AA$, respectively $(0.022$, 0.006 and $0.008 \AA$ from theory). The C-P-C bond angles are essentially unvaried in the four structures, with the only exception of the $\mathrm{C}_{\text {aliph }}-\mathrm{P}-\mathrm{C}_{\text {aliph }}$ angle, which as expected undergoes a small but non negligible increase, equal to $1.8(2)^{\circ}$, well reproduced by calculations $\left(1.3^{\circ}\right)$, going from $1 \mathrm{~g}$ to $2 \mathrm{a}$. 


\subsection{Polymerization of 1,3-Butadiene}

The polymerization of 1,3-butadiene with all the vanadium(III) phosphine complexes synthesized, in the presence of white solid MAO [dMAO, prepared by removing toluene and $\mathrm{AlMe}_{3}$ from commercially available MAO (sMAO)] or sMAO as co-catalyst, was examined. The polymerization runs were carried out in toluene at room temperature. The most significant results are summarized in Table 2.

All the vanadium complexes, in combination with $\mathrm{dMAO}$, were active in the polymerization of 1,3-butadiene, giving low to good polymer yields, ranging from 13 to 57\% (Table 2, entry 17 and 1 , respectively), within the first $2 \mathrm{~h}$ of polymerization. By extending the polymerization runs up to $24 \mathrm{~h}$, it was possible to reach complete monomer consumption (Table 2, entry 2), meaning that the catalysts are not deactivated with time, as it occurs in the polymerization of ethylene where high concentration of reoxidant (typically $\mathrm{Cl}_{3} \mathrm{CCOOEt}$ or chlorinated hydrocarbons) is required to keep the catalyst active [30,40,41]. This can be ascribed to the higher nucleophilicity of 1,3-butadiene with respect to a simple olefin, but mainly to the higher stability of the vanadium- $\pi$-allyl bond compared to the vanadium-alkyl bond of the intermediate species involved in the polymerization of 1,3-butadiene and ethylene, respectively [42].

The results in Table 2 are presented as a function of the phosphine donor ability [as measured by the electronic parameter $v_{\mathrm{CO}}$ based on the carbonyl stretching frequencies in $\mathrm{Ni}(\mathrm{CO})_{3} \mathrm{~L}$ complexes ( $\mathrm{L}=$ phosphine ligand)] and steric properties (measured by cone angle, $\theta$ ) as defined by Tolman [43,44], to highlight the influence of the ligand (i.e., the type of substituents on the phosphorous atoms) on the catalytic activity and selectivity. A general increasing of the activity by decreasing the $\sigma$-donor character (increasing $\pi$-acceptor character) of the phosphine ligand was observed, irrespective of the ligand steric hindrance. Electron-withdrawing groups on the ligand framework seem to enhance catalytic performance. Complexes with aryl phosphine exhibited higher activity than those bearing alkyl phosphines, as shown in Figure 2 (catalyst using PCyp 3 makes an exception to this trend). The $\mathrm{P}^{t} \mathrm{Bu}_{3}$ (the strongest $\sigma$-donor) yields the least active system, confirming the strong influence of the phosphine basicity on the catalytic activity.

Table 2. Polymerization of 1,3-butadiene with the phosphine V(III) complexes a

\begin{tabular}{|c|c|c|c|c|c|c|c|c|c|}
\hline \multirow[b]{2}{*}{ Entry } & \multirow[b]{2}{*}{ Catalyst } & \multicolumn{3}{|c|}{ Phosphine } & \multirow[b]{2}{*}{$\begin{array}{l}\text { Yield } \\
(\%)\end{array}$} & \multirow[b]{2}{*}{$\begin{array}{c}N^{\mathrm{d}} \\
\left(\mathrm{h}^{-1}\right)\end{array}$} & \multirow[b]{2}{*}{$\begin{array}{c}\text { cis:trans:1,2 e } \\
\text { (mol \%) }\end{array}$} & \multirow[b]{2}{*}{$\begin{array}{c}M_{\mathrm{w}}^{\mathrm{f}} \\
\left(\times 10^{3}\right)\end{array}$} & \multirow[b]{2}{*}{$M_{\mathrm{w}} / M_{\mathrm{n}}{ }^{\mathrm{f}}$} \\
\hline & & (Type) & $\begin{array}{l}v_{\mathrm{CO}}{ }^{b} \\
\left(\mathrm{~cm}^{-1}\right)\end{array}$ & $\begin{array}{l}\theta^{\mathrm{c}} \\
\left(^{\circ}\right)\end{array}$ & & & & & \\
\hline 1 & 1a/dMAO & $\mathrm{PPh}_{3}$ & 2068.9 & 145 & 57 & 739 & $33: 31: 36$ & 275 & 1.9 \\
\hline $2 *$ & 1a/dMAO & $\mathrm{PPh}_{3}$ & 2068.9 & 145 & 100 & 123 & $30: 34: 36$ & 290 & 1.6 \\
\hline $3^{*}$ & 1a/sMAO & $\mathrm{PPh}_{3}$ & 2068.9 & 145 & 51 & 63 & $65: 19: 16$ & 177 & 4.2 \\
\hline 4 & 1b/dMAO & $\mathrm{PMePh}_{2}$ & 2067.0 & 136 & 46 & 593 & 29:37:34 & 270 & 2.1 \\
\hline 5 & $1 \mathrm{~b} / \mathrm{sMAO}$ & $\mathrm{PMePh}_{2}$ & 2067.0 & 136 & 7 & 93 & $69: 17: 14$ & 164 & 1.9 \\
\hline 6 & 1c/dMAO & $\mathrm{PEtPh}_{2}$ & 2066.7 & 140 & 42 & 360 & $30: 38: 32$ & 83 & 2.1 \\
\hline 7 & 1d/dMAO & $\mathrm{PiPrPh}_{2}$ & 2065.7 & 150 & 50 & 648 & 28:33:39 & 112 & 3.5 \\
\hline 8 & 1d/sMAO & $\mathrm{PiPrPh}_{2}$ & 2065.7 & 150 & 17 & 222 & $66: 18: 16$ & 102 & 2.6 \\
\hline 9 & 1e/dMAO & $\mathrm{PCyPh}_{2}$ & 2064.8 & 153 & 46 & 593 & $37: 28: 35$ & 116 & 3.0 \\
\hline 10 * & 1e/sMAO & $\mathrm{PCyPh}_{2}$ & 2064.8 & 153 & 43 & 46 & $67: 15: 18$ & 100 & 2.9 \\
\hline
\end{tabular}


Table 2. Cont.

\begin{tabular}{|c|c|c|c|c|c|c|c|c|c|}
\hline 11 & 1f/dMAO & $\mathrm{PMe}_{2} \mathrm{Ph}$ & 2065.3 & 122 & 43 & 556 & $41: 20: 39$ & 75 & 3.8 \\
\hline 12 & 1g/dMAO & $\mathrm{PEt}_{2} \mathrm{Ph}$ & 2063.7 & 136 & 37 & 480 & $36: 24: 38$ & 97 & 2.7 \\
\hline 13 & 1h/dMAO & $\mathrm{PCy}_{2} \mathrm{Ph}$ & 2060.6 & 159 & 25 & 324 & $14: 73: 13$ & 274 & 2.8 \\
\hline 14 & $\mathbf{2 a} / \mathrm{dMAO}$ & $\mathrm{PCyp}_{3}$ & & & 36 & 472 & $46: 33: 21$ & 183 & 3.5 \\
\hline 15 & $2 \mathrm{~b} / \mathrm{dMAO}$ & $\mathrm{PC}_{3}$ & 2056.4 & 170 & 21 & 269 & $34: 46: 20$ & 193 & 3.3 \\
\hline 16 & 2c/dMAO & $\mathrm{PnPr}_{3}$ & 2059.1 & 132 & 26 & 333 & $36: 21: 43$ & 296 & 1.8 \\
\hline 17 & 2d/dMAO & $\mathrm{PtBu}_{3}$ & 2056.1 & 182 & 13 & 167 & $45: 34: 21$ & 253 & 3.1 \\
\hline
\end{tabular}

${ }^{a}$ polymerization conditions: 1,3-butadiene, $2 \mathrm{~mL}(1.4 \mathrm{~g})$; solvent, toluene $(16 \mathrm{~mL}) ; \mathrm{V}(\mathrm{III})$-complex, $10 \mu \mathrm{mol} ; \mathrm{Al} / \mathrm{V}$, 1000; time, $2 \mathrm{~h}\left({ }^{*} 24 \mathrm{~h}\right.$ in runs 2,3 and 10$) ;{ }^{b}$ measure of the electron-donating properties of phosphine ligands, as reported by Tolman [43,44]; ${ }^{\mathrm{c}}$ phosphine cone angle, as reported by Tolman $[43,44] ;{ }^{\mathrm{d}} \mathrm{N}=$ moles of 1,3 -butadiene polymerized per mol of vanadium per hour; ${ }^{\mathrm{e}}$ determined by ${ }^{1} \mathrm{H}$ and ${ }^{13} \mathrm{C} \mathrm{NMR} ;{ }^{f}$ determined by SEC.

The type of phosphine ligand was also found to have some effect, though not very pronounced, on the polymerization selectivity, as suggested by the microstructure of the resulting poly(1,3-butadiene)s determined by ${ }^{1} \mathrm{H}$ and ${ }^{13} \mathrm{C}$ NMR (Table 2 and Figures S1-S4). Generally, all the vanadium complexes, in combination with $\mathrm{dMAO}$, gave polymers with a mixed cis-1,4/trans-1,4/1,2 structure, the 1,4 and 1,2 units being randomly distributed along the polymer chain, as indicated by the fact that fractionation of the polymers with boiling solvents always gives polymeric fractions having practically the same structure of the pristine polymers; however, the 1,4 content seems to be higher for poly(1,3-butadiene)s obtained with catalysts based on vanadium complexes bearing more hindered phosphine ligands $\left(\theta \geq 150^{\circ}\right)$.

The influence of the type of alkylating agent (dMAO versus $\mathrm{SMAO}$ ) on the catalytic activity and selectivity was also investigated: under the same polymerization conditions, catalysts using sMAO as co-catalyst resulted to be less active, giving polymers with higher 1,4 content, the cis- 1,4 units being predominant (Table 2, entry 4 vs. 5, entry 2 vs. 3, entry 7 vs. 8 , and entry 9 vs. 10).

A spread of the weight-average molecular weights, depending on the complex used, ranging from rather low $\left(M_{\mathrm{w}}=75,000 \mathrm{~g} / \mathrm{mol}\right.$, entry 11$)$ to significantly higher $\left(M_{\mathrm{w}}=296,000 \mathrm{~g} / \mathrm{mol}\right.$, entry 16$)$, was observed. The molecular weight distributions $\left(M_{\mathrm{W}} / M_{\mathrm{n}}\right)$ were fairly narrows, although tending to a certain broadening in some cases.

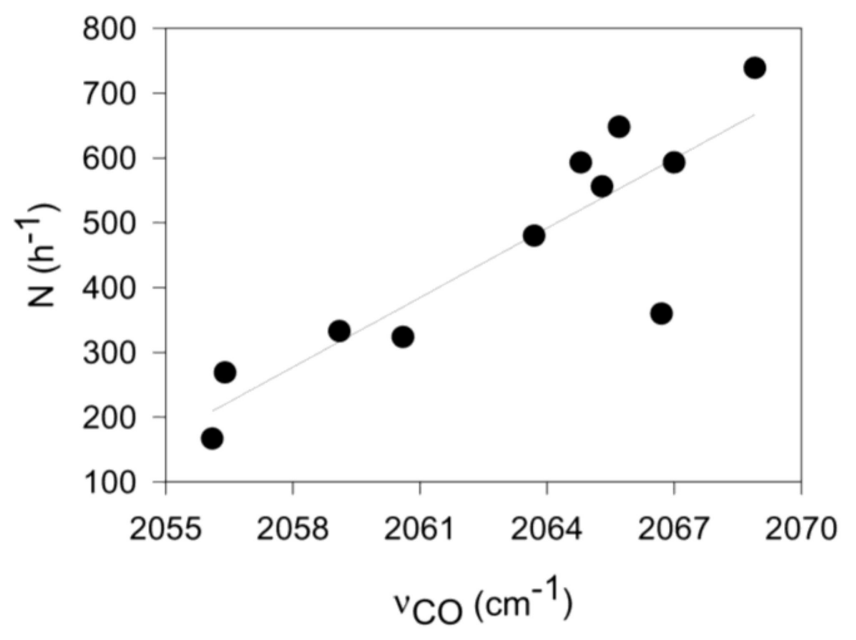

Figure 2. Plot of $\mathrm{N}$ (moles of 1,3-butadiene polymerized per mol of vanadium per hour) vs. the phosphine donor ability [as measured by the electronic parameter $v_{\mathrm{CO}}$ based on the carbonyl stretching frequencies in $\mathrm{Ni}(\mathrm{CO})_{3} \mathrm{~L}$ complexes $(\mathrm{L}=$ phosphine ligand)] as defined by Tolman $[43,44]$.

Finally, by comparing the results obtained with the vanadium systems described in the present paper with those obtained with catalysts based on other transition metals phosphine complexes (e.g., $\mathrm{Cr}, \mathrm{Co}, \mathrm{Fe}$ and $\mathrm{Ti}$ ), we can draw the following conclusions: (i) as far as catalytic activity is 
concerned, at the same polymerization conditions (i.e., monomer and catalyst concentration, solvent and temperature polymerization), vanadium systems are considerably less active than chromium (e.g., $\mathrm{CrCl}_{2}$ (dmpe) $)_{2} / \mathrm{MAO}$ ) [15] and cobalt (e.g., $\left.\mathrm{CoCl}_{2}\left(\mathrm{P}^{i} \mathrm{PrPh}_{2}\right)_{2} / \mathrm{MAO}\right)$ [18] ones, while they are comparable to those titanium-based (e.g., $\mathrm{TiCl}_{2}$ (dmpe) 2 /MAO) [39] and clearly more active than the iron-based ones [39] just because the latter are practically inactive; (ii) concerning instead the catalytic selectivity, vanadium systems are characterized by the lowest stereospecificity since they essentially provide poly(1,3-butadiene)s with mixed 1,4/1,2 structure, while titanium based systems allow to obtain predominantly cis-1,4 poly(1,3-butadiene)s $(\geq 80 \%$ ) [39] and cobalt based systems can give highly cis-1,4 or highly 1,2 syndiotactic poly(1,3-butadiene)s, depending on the type of phosphine ligand on the cobalt atom [18-20,39].

\section{Materials and Methods}

\subsection{General Procedures and Materials}

Manipulations of air- and/or moisture-sensitive materials were carried out under an inert atmosphere using a dual vacuum/nitrogen line and standard Schlenk-line techniques. Nitrogen was purified by passage over columns of $\mathrm{CaCl}_{2}$, molecular sieves and BTS catalysts. THF (Aldrich, St. Louis, MO, USA, $\geq 99.9 \%$ ) was refluxed over $\mathrm{Na}$ /benzophenone alloy for eight $\mathrm{h}$ and then distilled and stored over molecular sieves. Toluene (Aldrich, $>99.5 \%$ ) was refluxed over $\mathrm{Na}$ for $8 \mathrm{~h}$ and then distilled and stored over molecular sieves. Pentane (Aldrich, $>99 \%$ ) was refluxed over $\mathrm{Na} / \mathrm{K}$ alloy for eight $\mathrm{h}$ and then distilled and stored over molecular sieves. Tri-normal-propylphosphine $\left(\mathrm{P}^{\mathrm{n}} \mathrm{Pr}_{3}\right)$ (Strem, Newburyport, MA, USA, 95\%), tricyclopentylphosphine ( $\left.\mathrm{PCyp}_{3}\right)(\mathrm{Strem},>97 \%)$, tricyclohexylphosphine ( $\left.\mathrm{PCy}_{3}\right)(\mathrm{Strem}, 97 \%)$, methyldiphenylphosphine $\left(\mathrm{PMePh}_{2}\right)(\mathrm{Strem}, 99 \%)$, dimethylphenylphosphine $\left(\mathrm{PMe}_{2} \mathrm{Ph}\right)(\mathrm{Strem}, 99 \%)$, ethyldiphenylphosphine $\left(\mathrm{PEtPh}_{2}\right)$ (Aldrich, 98\%), diethylphenylphosphine ( $\left.\mathrm{PEt}_{2} \mathrm{Ph}\right)$ (Aldrich, 96\%), di-tert-butylmethylphosphine $\left(\mathrm{P}^{t} \mathrm{Bu}_{2} \mathrm{Me}\right)$ (Strem, $\left.>98 \%\right)$, iso-propyldiphenylphosphine $\left(\mathrm{P}^{i} \mathrm{PrPh}_{2}\right)$ (Aldrich, 97\%), cyclohexyldiphenylphosphine $\left(\mathrm{PCyPh}_{2}\right)$ (Strem, 99\%), dicyclohexylphenylphosphine $\left(\mathrm{PCy}{ }_{2} \mathrm{Ph}\right)$ (Aldrich, 95\%), triphenylphosphine $\left(\mathrm{PPh}_{3}\right)$ (Aldrich, $\left.\geq 95 \%\right)$, tri-tert-butylphosphine $\left(\mathrm{P}^{t} \mathrm{Bu}_{3}\right)$ (Aldrich, 95\%), $\mathrm{MAO}$ (Aldrich, $10 \mathrm{wt} \%$ solution in toluene) and $\mathrm{VCl}_{3}(\mathrm{THF})_{3}$ (Aldrich) were used as received. Solid MAO (dMAO) was prepared by removing toluene and unreacted free trimethylaluminum under vacuum from commercially available MAO solution (sMAO). The resulting white powder was heated further to $50{ }^{\circ} \mathrm{C}$ under vacuum overnight. 1,3-Butadiene (Air Liquide, Milano, Italy, $>99.5 \%$ pure) was evaporated from the container prior to each run, dried by passing through a column packed with molecular sieves and condensed into the reactor which had been precooled to $-20^{\circ} \mathrm{C}$. Deuterated solvent for NMR measurements $\left(\mathrm{C}_{2} \mathrm{D}_{2} \mathrm{Cl}_{4}\right)$ (Aldrich, $>99.5 \%$ atom D), was used as received. For the Elemental Analysis a Perkin Elmer CHN Analyzer 2400 Series II (Perkin Elmer, Milano, Italy) was used.

\subsection{Synthesis of the V(III)-Phosphine Complexes}

\subsubsection{Trichlorobis(triphenylphosphine)vanadium(III) $\left[\mathrm{VCl}_{3}\left(\mathrm{PPh}_{3}\right)_{2}, \mathbf{1 a}\right]$}

$\mathrm{PPh}_{3}(2.08 \mathrm{~g}, 10.6 \mathrm{mmol})$ was added to a suspension of $\mathrm{VCl}_{3}(\mathrm{THF})_{3}(0.99 \mathrm{~g}, 2.65 \mathrm{mmol}, \mathrm{P} / \mathrm{V}=4: 1)$ in toluene $(15 \mathrm{~mL})$ at room temperature. The solution turned rapidly brown, it was kept under stirring overnight, and then concentrated to half of its volume. Pentane $(50 \mathrm{~mL})$ was added dropwise and a light brown precipitate was rapidly formed. The suspension was filtered and the solid residue on the filter washed with pentane $(3 \times 20 \mathrm{~mL})$, then dried under vacuum to give 1a as lilac powder (Yield, 83\%). Attempts to obtain crystals suitable for the molecular structure determination failed. FTIR (cm $\left.{ }^{-1}\right)$ : $3054(\mathrm{vw}), 1589(\mathrm{w}), 1482(\mathrm{w}), 1436(\mathrm{~m}), 1158(\mathrm{~m}), 1119(\mathrm{~m}), 1093(\mathrm{~m}), 991(\mathrm{~m}), 748(\mathrm{mw})$, 723 (s), 692 (s), 533 (s), 496 (mw). Anal. Calcd. for $\mathrm{C}_{36} \mathrm{H}_{30} \mathrm{Cl}_{3} \mathrm{P}_{2} \mathrm{~V}: \mathrm{C}, 63.41 ; \mathrm{H}, 4.43 ; \mathrm{Cl}, 15.60 ; \mathrm{P}, 9.08 ; \mathrm{V}$, 7.47. Found: C, 63.30; H, 4.50; Cl, 15.50; P, 9.0; V, 7.60. 


\subsubsection{Trichlorobis(methyldiphenylphosphine)vanadium(III) $\left[\mathrm{VCl}_{3}\left(\mathrm{PMePh}_{2}\right)_{2}, \mathbf{1 b}\right]$}

$\mathbf{1 b}$ was synthesized in the same way as described for $\mathbf{1 a}$ using $\mathrm{PMePh}_{2}(2.19 \mathrm{~g}, 11 \mathrm{mmol})$ and $\mathrm{VCl}_{3}(\mathrm{THF})_{3}(1.02 \mathrm{~g}, 2.73 \mathrm{mmol}, \mathrm{P} / \mathrm{V}=4: 1)$, and it was obtained as red-purple powder (Yield, $90 \%$ ). The solid was then extracted continuously with boiling pentane. Crystals of $\mathbf{1 b}$ were formed directly on the bottom of the Schlenk tube during the extraction, and further crops of crystals were obtained by cooling the supernatant pentane solution at $-30{ }^{\circ} \mathrm{C}$ [30]. FTIR $\left(\mathrm{cm}^{-1}\right): 3053(\mathrm{w}), 1588(\mathrm{w}), 1483(\mathrm{mw})$, 1435 (m), 1296 (w), 1130 (s), 1096 (m), 1026 (w), 994 (m), 885 (s), 780 (mw) 741 (vs), 690 (vs), 505 (s), 477 (m). Anal. Calcd. for $\mathrm{C}_{26} \mathrm{H}_{26} \mathrm{Cl}_{3} \mathrm{P}_{2} \mathrm{~V}: \mathrm{C}, 55.99 ; \mathrm{H}, 4.70 ; \mathrm{Cl}, 19.07 ; \mathrm{P}, 11.11 ; \mathrm{V}, 9.13$. Found: $\mathrm{C}, 56.20$; $\mathrm{H}, 4.60 ; \mathrm{Cl}, 19.20 ; \mathrm{P}, 11.10 ; \mathrm{V}, 9.20$.

\subsubsection{Trichlorobis(ethyldiphenylphosphine)vanadium(III) $\left[\mathrm{VCl}_{3}\left(\mathrm{PEtPh}_{2}\right)_{2}, 1 \mathrm{c}\right]$}

1c was synthesized in the same way as described for 1a using PEtPh $2(2.9 \mathrm{~g}, 13.7 \mathrm{mmol})$ and $\mathrm{VCl}_{3}(\mathrm{THF})_{3}(1.28 \mathrm{~g}, 3.42 \mathrm{mmol})$, and it was obtained as lilac powder (Yield, 91\%). The solid was then extracted continuously with boiling pentane. Crystals of 1c were formed directly on the bottom of the Schlenk tube during the extraction, and further crops of crystals were obtained by cooling the supernatant pentane solution at $-30^{\circ} \mathrm{C}$. FTIR $\left(\mathrm{cm}^{-1}\right)$ : $3054(\mathrm{vw}), 2927(\mathrm{vs}), 1587(\mathrm{vw}), 1484(\mathrm{w})$, $1436(\mathrm{~m}), 1144(\mathrm{~m}), 1120(\mathrm{~m}), 1098(\mathrm{~m}), 1028(\mathrm{w}), 997(\mathrm{~m}), 908(\mathrm{w}), 734(\mathrm{~s}), 691(\mathrm{vs}), 539(\mathrm{~m}), 506(\mathrm{~m})$, 481 (m). Anal. Calcd. for $\mathrm{C}_{28} \mathrm{H}_{30} \mathrm{Cl}_{3} \mathrm{P}_{2} \mathrm{~V}$ : C, 57.41; H, 5.16; Cl, 18.16; P, 10.58; V, 8.70. Found: C, 57.40; $\mathrm{H}, 5.10 ; \mathrm{Cl}, 18.20 ; \mathrm{P}, 10.07 ; \mathrm{V}, 8.60$.

\subsubsection{Trichlorobis(iso-propyldiphenylphosphine)vanadium(III) $\left[\mathrm{VCl}_{3}\left(\mathrm{P}^{i} \mathrm{PrPh}_{2}\right)_{2}, \mathbf{1 d}\right]$}

1d was synthesized in the same way as described for $1 \mathrm{a}$ using $\mathrm{P}^{i} \mathrm{PrPh}_{2}(2.0 \mathrm{~g}, 8.76 \mathrm{mmol})$ and $\mathrm{VCl}_{3}(\mathrm{THF})_{3}(0.82 \mathrm{~g}, 2.19 \mathrm{mmol})$, and it was obtained as pink powder (Yield, 91\%). FTIR $\left(\mathrm{cm}^{-1}\right)$ : $3054(\mathrm{vw}), 2963(\mathrm{w}), 1587(\mathrm{w}), 1482(\mathrm{w}), 1460(\mathrm{w}), 1437(\mathrm{~m}), 1153(\mathrm{~m}), 1120(\mathrm{~m}), 1100(\mathrm{~m}), 1026(\mathrm{~m})$, $992(\mathrm{~m}), 879(\mathrm{w}), 740(\mathrm{~s}), 691(\mathrm{vs}), 538(\mathrm{~m}), 521(\mathrm{~s}), 509(\mathrm{~s}), 490(\mathrm{~m}), 460(\mathrm{~m})$. Anal. Calcd. for $\mathrm{C}_{30} \mathrm{H}_{34} \mathrm{Cl}_{3} \mathrm{P}_{2} \mathrm{~V}: \mathrm{C}, 58.70 ; \mathrm{H}, 5.58$. Found: $\mathrm{C}, 58.64 ; \mathrm{H}, 5.54$.

\subsubsection{Trichlorobis(cyclohexyldiphenylphosphine)vanadium(III) $\left[\mathrm{VCl}_{3}\left(\mathrm{PCyPh}_{2}\right)_{2}, \mathbf{1 e}\right]$}

1e was synthesized in the same way as described for 1a using $\mathrm{PCyPh}_{2}(2.4 \mathrm{~g}, 9.0 \mathrm{mmol})$ and $\mathrm{VCl}_{3}(\mathrm{THF})_{3}(0.86 \mathrm{~g}, 2.3 \mathrm{mmol})$, and it was obtained as light blue powder (Yield, 56\%). Attempts to obtain crystals useful to determine the structure of the complex failed. FTIR $\left(\mathrm{cm}^{-1}\right): 3055(\mathrm{vw})$, $2930(\mathrm{~m}), 2875(\mathrm{w}), 1589(\mathrm{w}), 1483(\mathrm{w}), 1437(\mathrm{~m}), 1152(\mathrm{~m}), 1118(\mathrm{~s}), 1097(\mathrm{~m}), 1028(\mathrm{w}), 999(\mathrm{~s}), 917(\mathrm{w})$, $888(\mathrm{w}), 851(\mathrm{w}), 822(\mathrm{w}), 741(\mathrm{~s}), 724(\mathrm{~s}), 690(\mathrm{vs}), 554(\mathrm{~s}), 529(\mathrm{vs}), 499(\mathrm{~m}), 486(\mathrm{~m}), 463(\mathrm{w})$. Anal. Calcd. for $\mathrm{C}_{36} \mathrm{H}_{42} \mathrm{Cl}_{3} \mathrm{P}_{2} \mathrm{~V}$ : C, 62.31; H, 6.10; $\mathrm{Cl}, 15.33 ; \mathrm{P}, 8.93 ; \mathrm{V}, 7.34$. Found: $\mathrm{C}, 62.40 ; \mathrm{H}, 6.30 ; \mathrm{Cl}, 15.50 ; \mathrm{P}, 9.0$; $\mathrm{V}, 7.20$.

\subsubsection{Trichlorobis(dimethyiphenylphosphine)vanadium(III) $\left[\mathrm{VCl}_{3}\left(\mathrm{PMe}_{2} \mathrm{Ph}\right)_{2}, \mathbf{1 f}\right]$}

1f was synthesized in the same way as described for 1a using $\mathrm{PMe}_{2} \mathrm{Ph}(1.06 \mathrm{~g}, 7.7 \mathrm{mmol})$ and $\mathrm{VCl}_{3}(\mathrm{THF})_{3}(0.72 \mathrm{~g}, 1.92 \mathrm{mmol})$, and it was obtained as pale pink powder (Yield, $\left.87 \%\right)$. Attempts to obtain crystals useful to determine the structure of the complex failed. FTIR $\left(\mathrm{cm}^{-1}\right)$ : $3053(\mathrm{w})$, 1435 (mw), 1140 (mw), 997 (mw), 951 (m), 840 (mw), 745 (vs), 693 (vs), 485 (m). Anal. Calcd. for $\mathrm{C}_{16} \mathrm{H}_{22} \mathrm{Cl}_{3} \mathrm{P}_{2} \mathrm{~V}: \mathrm{C}, 44.32 ; \mathrm{H}, 5.11$. Found: $\mathrm{C}, 44.50 ; \mathrm{H}, 5.20$.

\subsubsection{Trichlorobis(diethylphenylphosphine)vanadium(III) $\left[\mathrm{VCl}_{3}\left(\mathrm{PEt}_{2} \mathrm{Ph}\right)_{2}, \mathbf{1 g}\right]$}

$\mathrm{PEt}_{2} \mathrm{Ph}(1.0 \mathrm{~g}, 6.1 \mathrm{mmol})$ was added dropwise to a suspension of $\mathrm{VCl}_{3}(\mathrm{THF})_{3}(0.85 \mathrm{~g}, 2.26 \mathrm{mmol}$, $\mathrm{P} / \mathrm{V}=2.6: 1)$ in THF $(25 \mathrm{~mL})$ at room temperature. The solution turned from dark red to green rapidly and was kept under stirring overnight, then concentrated to half of its volume. Pentane $(50 \mathrm{~mL})$ was added dropwise and a beige oily product formed. The mixture was kept under stirring overnight. The solvent was discarded, leaving the oily product behind, washed with pentane $(3 \times 40 \mathrm{~mL})$ and 
finally dried in vacuo. A successive addition of a large excess of pentane, and leaving at $-30{ }^{\circ} \mathrm{C}$ for $3 \mathrm{~h}$ produced green chunks of $\mathbf{1 g}$ (Yield, $85 \%$ ). Crystals of $1 \mathrm{~g}$ were formed directly on the bottom of the Schlenk tube during the extraction, and further crops of crystals were obtained by cooling the supernatant pentane solution at $-30^{\circ} \mathrm{C}$. FTIR $\left(\mathrm{cm}^{-1}\right)$ : $3054(\mathrm{vw}), 2938(\mathrm{w}), 1589(\mathrm{w}), 1485(\mathrm{w}), 1455(\mathrm{~m})$, 1438 (s), 1398 (m), 1268 (w), 1248 (w), 1130 (vs), 1107 (vs), 1072 (s), 1049 (s), 1020 (s), 1001 (vs), 934 (w), $898(\mathrm{w}), 762$ (s), 746 (s), 725 (s), 678 (s), 515 (s), 477 (m). Anal. Calcd. for $\mathrm{C}_{20} \mathrm{H}_{30} \mathrm{Cl}_{3} \mathrm{P}_{2} \mathrm{~V}: \mathrm{C}, 49.05 ; \mathrm{H}$, 6.17. Found: $\mathrm{C}, 49.17 ; \mathrm{H}, 6.23$.

\subsubsection{Trichlorobis(dicyclohexylphenylphosphine)vanadium(III) $\left[\mathrm{VCl}_{3}\left(\mathrm{PCy}_{2} \mathrm{Ph}\right)_{2}, \mathbf{1 h}\right]$}

1h was synthesized in the same way as described for $1 \mathrm{~g}$ using $\mathrm{PCy}_{2} \mathrm{Ph}(1.0 \mathrm{~g}, 3.65 \mathrm{mmol})$ and $\mathrm{VCl}_{3}(\mathrm{THF})_{3}(0.55 \mathrm{~g}, 1.48 \mathrm{mmol})$, and it was obtained as light green powder (Yield, $76 \%$ ). Attempts to obtain crystals useful to determine the structure of the complex failed. FTIR ( $\left.\mathrm{cm}^{-1}\right)$ : $3054(\mathrm{w}), 2924$ (vs), $2851(\mathrm{~s}), 1588(\mathrm{w}), 1439(\mathrm{~s}), 1328(\mathrm{w}), 1299(\mathrm{w}), 1271(\mathrm{w}), 1177(\mathrm{w}), 1125(\mathrm{~m}), 1069(\mathrm{w}), 1003(\mathrm{~s}), 905(\mathrm{~m})$, $850(\mathrm{~m}), 747$ (s), 696 (s), $530(\mathrm{~m}), 493(\mathrm{~m})$. Anal. Calcd. for $\mathrm{C}_{36} \mathrm{H}_{54} \mathrm{Cl}_{3} \mathrm{P} 2 \mathrm{~V}: \mathrm{C}, 61.24 ; \mathrm{H}, 7.71$. Found: $\mathrm{C}$, 61.19; H, 7.68 .

\subsubsection{Trichlorobis(tricyclopentylphosphine)vanadium(III) $\left[\mathrm{VCl}_{3}\left(\mathrm{PCyp}_{3}\right)_{2}, \mathbf{2 a}\right]$}

2a was synthesized in the same way as described for $\mathbf{1 a}$ using РСyp $_{3}(2.9 \mathrm{~g}, 13.7 \mathrm{mmol})$ and $\mathrm{VCl}_{3}(\mathrm{THF})_{3}(0.92 \mathrm{~g}, 2.44 \mathrm{mmol})$, and it was obtained as a pink powder (Yield, 65\%). The solid was then extracted continuously with boiling pentane. Crystals of 2 a were formed directly on the bottom of the Schlenk tube during the extraction, and further crops of crystals were obtained by cooling the supernatant pentane solution at $-30^{\circ} \mathrm{C}$. FTIR ( $\left.\mathrm{cm}^{-1}\right)$ : 2949 (vs), 2866 (vs), 1448 (m), 1299 (mw), $1261(\mathrm{mw}), 1231(\mathrm{mw}), 1126(\mathrm{~m}), 1053(\mathrm{~m}), 1028(\mathrm{~m}), 994$ (vs), 907 (mw), 806 (s), $508(\mathrm{~m}), 487(\mathrm{~m})$. Anal. Calcd. for $\mathrm{C}_{30} \mathrm{H}_{54} \mathrm{Cl}_{3} \mathrm{P}_{2} \mathrm{~V}: \mathrm{C}, 56.83 ; \mathrm{H}, 8.59 ; \mathrm{Cl}, 16.78 ; \mathrm{P}, 9.77 ; \mathrm{V}, 8.03$. Found: $\mathrm{C}, 56.90 ; \mathrm{H}, 8.70 ; \mathrm{Cl}$, 16.70; P, 9.80; V, 8.0.

\subsubsection{Trichlorobis(tricyclohexylphosphine)vanadium(III) $\left[\mathrm{VCl}_{3}\left(\mathrm{PCy}_{3}\right)_{2}, \mathbf{2 b}\right]$}

$\mathbf{2 b}$ was synthesized in the same way as described for $\mathbf{1 g}$ using $\mathrm{PC}_{3}(2.47 \mathrm{~g}, 8.82 \mathrm{mmol})$ and $\mathrm{VCl}_{3}(\mathrm{THF})_{3}(0.83 \mathrm{~g}, 2.20 \mathrm{mmol})$, and it was obtained as a light grey powder (Yield, 55\%). Attempts to obtain crystals useful to determine the structure of the complex failed. FTIR $\left(\mathrm{cm}^{-1}\right): 3277(\mathrm{vw})$, 2927 (vs), 2851 (vs), 1446 (s), 1262 (w), 1107 (m), 1006 (vs), 900 (m), 851 (m), 802 (m), 519 (mw), 467 (mw). Anal. Calcd. for $\mathrm{C}_{36} \mathrm{H}_{66} \mathrm{Cl}_{3} \mathrm{P}_{2} \mathrm{~V}: \mathrm{C}, 60.21 ; \mathrm{H}, 9.26 ; \mathrm{Cl}, 14.81 ; \mathrm{P}, 8.63 ; \mathrm{V}, 7.09$. Found: $\mathrm{C}, 60.30$; $\mathrm{H}, 9.20 ; \mathrm{Cl}, 14.70 ; \mathrm{P} 8.70 \mathrm{~V}, 7.30$.

\subsubsection{Trichlorobis(tri-normal-propylphosphine)vanadium(III) $\left[\mathrm{VCl}_{3}\left(\mathrm{P}^{n} \mathrm{Pr}_{3}\right)_{2}, 2 \mathrm{c}\right]$}

2c was synthesized in the same way as described for $1 \mathrm{~g}$ using the ligand $\mathrm{P}^{n} \operatorname{Pr}_{3}(1.08 \mathrm{~g}, 6.72 \mathrm{mmol})$ and $\mathrm{VCl}_{3}(\mathrm{THF})_{3}(1.0 \mathrm{~g}, 2.7 \mathrm{mmol})$, and it was obtained as a beige powder (Yield, 35\%). Attempts to obtain crystals useful to determine the structure of the complex failed. FTIR $\left(\mathrm{cm}^{-1}\right): 2093(\mathrm{mw})$, $2933(\mathrm{mw}), 2874(\mathrm{mw}), 2903(\mathrm{mw}), 1461(\mathrm{~m}), 1403(\mathrm{~m}), 1380(\mathrm{mw}), 1243(\mathrm{vw}), 1071(\mathrm{~m}), 997(\mathrm{~m}), 916(\mathrm{~m})$, 733 (mw). Anal. Calcd. for $\mathrm{C}_{18} \mathrm{H}_{42} \mathrm{Cl}_{3} \mathrm{P}_{2} \mathrm{~V}: \mathrm{C}, 45.25 ; \mathrm{H}, 8.86$. Found: $\mathrm{C}, 45.10 ; \mathrm{H}, 8.78$.

\subsubsection{Trichlorobis(tri-tert-butylphosphine)vanadium(III) $\left[\mathrm{VCl}_{3}\left(\mathrm{P}^{t} \mathrm{Bu}_{3}\right)_{2}, \mathbf{2 d}\right]$}

$\mathbf{2 d}$ was synthesized in the same way as described above for $1 \mathrm{~g}$ using the ligand $\mathrm{P}^{t} \mathrm{Bu}_{3}$ $(1.74 \mathrm{~g}, 8.64 \mathrm{mmol})$ and $\mathrm{VCl}_{3}(\mathrm{THF})_{3}(0.46 \mathrm{~g}, 2.16 \mathrm{mmol})$, and it was obtained as gray /brown powder (Yield, 31\%). FTIR ( $\left.\mathrm{cm}^{-1}\right)$ : $3029(\mathrm{vw}), 2971(\mathrm{w}), 1592(\mathrm{w}), 1472(\mathrm{~m}), 1402(\mathrm{w}), 1379(\mathrm{w}), 1261(\mathrm{w})$, $1175(\mathrm{~m}), 1097(\mathrm{w}), 998(\mathrm{~s}), 934(\mathrm{w}), 871(\mathrm{~m}), 807(\mathrm{~m}), 732(\mathrm{w}), 672(\mathrm{~m}), 618(\mathrm{w}), 554(\mathrm{~m}), 493(\mathrm{~m}), 474(\mathrm{~m})$. Anal. Calcd. for $\mathrm{C}_{24} \mathrm{H}_{54} \mathrm{Cl}_{3} \mathrm{P}_{2} \mathrm{~V}: \mathrm{C}, 51.30 ; \mathrm{H}, 9.69 ; \mathrm{Cl}, 18.93 ; \mathrm{P}, 11.02 ; \mathrm{V}, 9.07$. Found: $\mathrm{C}, 51.50 ; \mathrm{H}, 9.50 ; \mathrm{Cl}$, 19.10; P, 11.20; V, 9.30 . 


\subsection{X-ray Crystallographic Studies}

The intensity data were collected on a Bruker Smart Apex CCD area detector using graphite-monochromated Mo K $\alpha$ radiation $(\lambda=0.71073 \AA)$. Data reduction was made using SAINT programs; absorption corrections based on multiscan were obtained by SADABS [45]. The structures were solved by SHELXS-97 [46], and refined on $\mathrm{F}^{2}$ by full-matrix least-squares using SHELXL-14 [47]. All the non-hydrogen atoms were refined anisotropically, hydrogen atoms were included as 'riding' and not refined. The isotropic thermal parameters of $\mathrm{H}$ atoms were fixed at 1.2 (1.5 for methyl groups) times the equivalent thermal parameter of the atoms to which they are bonded. Crystal data and results of the refinement: (1c) air-sensitive orange prism $0.50 \times 0.20 \times 0.20 \mathrm{~mm}, \mathrm{Mr}=585.75$, monoclinic, space group $\mathrm{P} 2{ }_{1} / \mathrm{c}, \mathrm{a}=8.3234(12) \AA, \mathrm{b}=9.7489(14) \AA, \mathrm{c}=34.500(5) \AA, \beta=93.804(2)^{\circ}$, $\mathrm{V}=2793.3(7) \AA^{3}, \mathrm{Z}=4, \mathrm{~T}=130(2) \mathrm{K}, \mu=0.773 \mathrm{~mm}^{-1}$. 37,054 measured reflections, 5141 independent reflections, 4377 reflections with $\mathrm{I}>2 \sigma(\mathrm{I}), 2.36<2 \theta<50.91^{\circ}, \mathrm{R}_{\text {int }}=0.0468$. Refinement on 5141 reflections, 309 parameters. Final $\mathrm{R}=0.0261, \mathrm{wR}=0.0564$ for data with $\mathrm{F}^{2}>2 \sigma\left(\mathrm{F}^{2}\right), \mathrm{S}=1.036,(\Delta / \sigma)_{\max }=0.001$, $\Delta \rho_{\max }=0.286, \Delta \rho_{\min }=-0.249 \mathrm{e}^{-3} ;(\mathbf{1 g})$ air-sensitive light blue tablet $0.25 \times 0.12 \times 0.10 \mathrm{~mm}, \mathrm{Mr}=489.67$, orthorhombic, space group P2 $22_{1} 21, a=11.9609(5) \AA, b=13.8664(5) \AA, c=13.9617(5) \AA, V=2315.61(15) \AA^{3}$, $\mathrm{Z}=4, \mathrm{~T}=150(2) \mathrm{K}, \mu=0.916 \mathrm{~mm}^{-1}$. 46,227 measured reflections, 6991 independent reflections, 6547 reflections with $\mathrm{I}>2 \sigma(\mathrm{I}), 4.49<2 \theta<60.84^{\circ}, \mathrm{R}_{\text {int }}=0.0364$. Refinement on 6991 reflections, 239 parameters. Final $\mathrm{R}=0.0485, \mathrm{wR}=0.1459$ for data with $\mathrm{F}^{2}>2 \sigma\left(\mathrm{F}^{2}\right), \mathrm{S}=1.076,(\Delta / \sigma)_{\max }=0.001, \Delta \rho_{\max }=1.109$, $\Delta \rho_{\min }=-1.955 \mathrm{e}^{-3}$; (2a) air-sensitive red tablet $0.50 \times 0.17 \times 0.15 \mathrm{~mm}, \mathrm{Mr}=633.96$, triclinic, space group P-1, $\mathrm{a}=9.9362(15) \AA, \mathrm{b}=11.7793(18) \AA, \mathrm{c}=14.673(2) \AA, \alpha=83.712(2)^{\circ}, \beta=89.645(2)^{\circ}, \gamma=66.242(2)^{\circ}$, $\mathrm{V}=1561.0(4) \AA^{3}, \mathrm{Z}=2, \mathrm{~T}=100(2) \mathrm{K}, \mu=0.696 \mathrm{~mm}^{-1} .16,969$ measured reflections, 4488 independent reflections, 3859 reflections with $\mathrm{I}>2 \sigma(\mathrm{I}), 2.80<2 \theta<46.60^{\circ}, \mathrm{R}_{\text {int }}=0.0395$. Refinement on 4488 reflections, 325 parameters. Final $\mathrm{R}=0.0385, \mathrm{wR}=0.0911$ for data with $\mathrm{F}^{2}>2 \sigma\left(\mathrm{F}^{2}\right), \mathrm{S}=1.066,(\Delta / \sigma)_{\max }=0.002$, $\Delta \rho_{\max }=0.606, \Delta \rho_{\min }=-0.940 \mathrm{e}^{-3}$. Table S1 contains cartesian coordinates of the modelled compounds at their UM06/6-311G(d) optimized geometry; while CCDC 1583626-1583628 contain supplementary crystallographic data which can be obtained free of charge from The Cambridge Crystallographic Data Centre via www.ccdc.cam.ac.uk/data_request/cif.

\subsection{Computational Details}

Geometry optimization of the isolated, gas phase vanadium(III) complexes were performed with the 6-311g(d) basis set by the Gaussian16 program package [48], starting from the respective $\mathrm{X}$-ray molecular structures. For comparative purposes, two exchange-correlation functionals have been used: the M06 functional [34], due to its specific parametrization on organometallic complexes, and the B3LYP functional [35-37], the most used functional for geometry optimizations. According to previous magnetic measurements on $\mathbf{1 b}$ [25], complexes were modeled in their triplet state through the unrestricted formalism.

\subsection{Polymerization of 1,3-Butadiene}

Polymerizations were carried out in a $25 \mathrm{~mL}$ round-bottomed Schlenk flask. Prior to starting polymerization, the reactor was heated to $110^{\circ} \mathrm{C}$ under vacuum for one $\mathrm{h}$ and backfilled with nitrogen. 1,3-Butadiene was condensed into the Schlenk flask kept at $-20^{\circ} \mathrm{C}$, then toluene was added and the solution was brought to the desired polymerization temperature. The aluminum alkyl and a toluene solution $(2 \mathrm{mg} / \mathrm{mL})$ of the vanadium complex were then added in that order. Polymerization was stopped with methanol containing a small amount of hydrochloric acid. The polymer obtained was then coagulated by adding $40 \mathrm{~mL}$ of a methanol solution containing $4 \%$ of Irganox ${ }^{\circledR} 1076$ antioxidant (BASF, Ludwigshafen am Rhein, Germany), repeatedly washed with fresh methanol and finally dried in vacuum at room temperature to constant weight. 


\subsection{Polymer Characterization}

For all the mentioned catalysts the FTIR spectrum was collected. Attenuated total reflectance (ATR)-Fourier transform infrared spectroscopy (FTIR) spectra were recorded at room temperature in the $600-4000 \mathrm{~cm}^{-1}$ range with a resolution of $4 \mathrm{~cm}^{-1}$ using a Perkin Elmer Spectrum Two spectrometer (Perkin Elmer, Milano, Italy.). NMR spectra were recorded on a Bruker NMR advance 400 Spectrometer (Bruker Italia Srl, Milano, Italy) operating at $400 \mathrm{MHz}(1 \mathrm{H})$ and $100.58 \mathrm{MHz}\left({ }^{13} \mathrm{C}\right)$ working in the PFT mode at $103{ }^{\circ} \mathrm{C}$. NMR samples were prepared dissolving from 60 to $80 \mathrm{mg}$ of polymer in about three $\mathrm{mL}$ of $\mathrm{C}_{2} \mathrm{D}_{2} \mathrm{Cl}_{4}$ in $10 \mathrm{~mm}$ probes and referred to hexamethyldisiloxane (HMDS), as internal standard. The relaxation delay was $16 \mathrm{~s}$. The molecular weight average $\left(M_{\mathrm{w}}\right)$ and the molecular weight distribution $\left(M_{\mathrm{W}} / M_{\mathrm{n}}\right)$ were obtained by a high temperature Waters GPCV2000 size exclusion chromatography (SEC) system equipped with a refractometer detector. The experimental conditions consisted of three PL Gel Olexis columns, ortho-dichlorobenzene (DCB) as the mobile phase, $0.8 \mathrm{~mL} / \mathrm{min}$ flow rate, and $145^{\circ} \mathrm{C}$ temperature. The calibration of the SEC system was constructed using eighteen narrow $M_{\mathrm{W}} / M_{\mathrm{n}}$ PS standards with molar weights ranging from 162 to $5.6 \times 10^{6} \mathrm{~g} / \mathrm{mol}$. For SEC analysis, about $12 \mathrm{mg}$ of polymer was dissolved in five $\mathrm{mL}$ of DCB with $0.05 \%$ of BHT as antioxidant.

\section{Conclusions}

A series of $\mathrm{V}(\mathrm{III})$ complexes with aryl and alkyl phosphines were synthesized and characterized, including single crystal X-ray molecular structure determination of $\mathrm{VCl}_{3}\left(\mathrm{PEtPh}_{2}\right)_{2}, \mathrm{VCl}_{3}\left(\mathrm{PEt}_{2} \mathrm{Ph}\right)_{2}$ and $\mathrm{VCl}_{3}\left(\mathrm{PCyp}_{3}\right)_{2}$. The complexes were then successfully used, in combination with various aluminoxanes, for the polymerization of 1,3-butadiene. In general, we obtained polymers having different microstructures, depending on the phosphine ligand and the Al-based activator. Catalysts based on vanadium complexes with more hindered ligands gave poly(1,3-butadiene)s with higher 1,4 (cis + trans) content $(\geq 80 \mathrm{~mol} \%)$; catalysts with sMAO as co-catalyst were found to give higher cis-1,4 content ( $\geq 65 \mathrm{~mol} \%$ ). The type of ligand and co-catalyst were also found to have some influence on the catalyst activity. In general catalysts based on complexes with aryl phosphines exhibited higher activity than those bearing alkyl phosphines; catalysts using dMAO instead of sMAO as co-catalyst resulted to be much more active, allowing to reach complete monomer conversion, thus indicating that vanadium catalysts in case of conjugated diolefins polymerization are not subject to deactivation and do not need the use of a reoxidant, as it happens in case of monoolefins.

Supplementary Materials: The following are available online at http:/ /www.mdpi.com/2073-4344/7/12/369/s1. Table S1: Cartesian coordinates of the modeled compounds at their UM06/6-311G(d) optimized geometry, Figure S1: ${ }^{1} \mathrm{H}$ NMR spectrum of poly(1,3-butadiene) (Table 2, entry 4), Figure S2: ${ }^{13} \mathrm{C}$ NMR spectrum of poly(1,3-butadiene) (Table 2, entry 4), Figure S3: ${ }^{1} \mathrm{H}$ NMR spectrum of poly(1,3-butadiene) (Table 2, entry 14), Figure S4: ${ }^{13} \mathrm{C}$ NMR spectrum of poly(1,3-butadiene) (Table 2, entry 14).

Author Contributions: G.L. performed the experiments, analyzed the data, and contributed to write the paper. G.Z. performed the experiments and a part of them were reproduced by I.P. and A.S.; A.F. determined the X-ray molecular structures of the complexes, performed the quantum-mechanical calculations and contributed to write the paper. G.R. was the principal investigator, conceived and designed the experiments, analyzed the data and wrote the paper.

Conflicts of Interest: The authors declare no conflict of interest.

\section{References}

1. Porri, L.; Giarrusso, A. Part II. In Conjugated Diene Polymerization in Comprehensive Polymer Science; Pergamon: Oxford, UK, 1989; Volume 4, pp. 53-108.

2. Thiele, S.K.-H.; Wilson, D.R. Alternate Transition Metal Complex Based Diene Polymerization. J. Macromol. Sci. Part C Polym. Rev. 2003, C43, 581-628. [CrossRef]

3. Friebe, L.; Nuyken, O.; Obrecht, W. Neodymium-Based Ziegler/Natta Catalysts and their Application in Diene Polymerization. Adv. Polym. Sci. 2006, 204, 1-154. 
4. Natta, G.; Porri, L.; Corradini, P.; Morero, D. Polimerizzazioni stereospecifiche di diolefine coniugate. Chim. Ind. 1958, 40, 362-371.

5. Natta, G.; Porri, L.; Carbonaro, A. Stereospecificity of homogeneous catalysts prepared from vanadium trichloride in the polymerization of conjugated diolefins. Atti Accad. Naz. Lincei Cl. Sci. Fis. Mat. Nat. Rend. 1961, 31, 189; reprinted in Chem. Abstr. 1962, 57, 4848.

6. Porri, L.; Carbonaro, A.; Ciampelli, F. Copolymerization of 1,3-butadiene and 1,3-pentadiene with homogeneous $\mathrm{Al}(\mathrm{C} 2 \mathrm{H} 5) 2 \mathrm{Cl}$-vanadium compounds catalyst systems. I. Preparation and properties of the copolymers. Makromol. Chem. 1963, 61, 90-103. [CrossRef]

7. Ricci, G.; Italia, S.; Comitani, C.; Porri, L. Polymerization of conjugated dialkenes with transition metal catalysts. Influence of methylaluminoxane on catalyst activity and stereospecificity. Polym. Commun. 1991, 32, 514-517.

8. Ricci, G.; Zetta, L.; Alberti, E.; Motta, T.; Canetti, M.; Bertini, F. Butadiene-isoprene copolymerization with $\mathrm{V}(\mathrm{acac})_{3}$-MAO. Crystalline and amorphous trans-1,4 copolymers. J. Polym. Sci. Part A Polym. Chem. 2007, 45, 4635-4646. [CrossRef]

9. Colamarco, E.; Milione, S.; Cuomo, C.; Grassi, A. Homo- and Copolymerization of Butadiene Catalyzed by an Bis(imino)pyridyl Vanadium Complex. Macromol. Rapid Commun. 2004, 25, 450-454. [CrossRef]

10. Natta, G.; Porri, L.; Zanini, G.; Fiore, L. Stereospecific polymerization of conjugated diolefins. IV. Preparation of syndiotactic 1,2-polybutadiene. Chim. Ind. (Milan) 1959, 41, 526-532; reprinted in Chem. Abstr. 1960, 54, 1258.

11. Porri, L.; Ricci, G.; Giarrusso, A. Metalorganic Catalysts for Synthesis and Polymerization; Kaminsky, W., Ed.; Springer: Berlin/Heidelberg, German, 1999; p. 519.

12. Porri, L.; Giarrusso, A.; Ricci, G. Metallocene-Based Polyolefins; Scheirs, J., Kaminsky, W., Eds.; John Wiley \& Sons Ltd.: London, UK, 2000; p. 115.

13. Ricci, G.; Panagia, A.; Porri, L. Polymerization of 1,3-dienes with catalysts based on mono-and bis-cyclopentadienyl derivatives of vanadium. Polymer 1996, 37, 363-365. [CrossRef]

14. Bradley, S.; Camm, K.D.; Furtado, S.J.; Gott, A.L.; McGowan, P.C.; Podesta, T.J.; Thornton-Pett, M. Synthesis and Structure of Amino-Functionalized Cyclopentadienyl Vanadium Complexes and Evaluation of Their Butadiene Polymerization Behavior. Organometallics 2002, 21, 3443-3453. [CrossRef]

15. Ricci, G.; Battistella, M.; Porri, L. Chemoselectivity and Stereospecificity of Chromium(II) Catalysts for 1,3-Diene Polymerization. Macromolecules 2001, 34, 5766-5769. [CrossRef]

16. Ricci, G.; Forni, A.; Boglia, A.; Sonzogni, M. New Chromium(II) Bidentate Phosphine Complexes: Synthesis, Characterization, and Behavior in the Polymerization of 1,3-Butadiene. Organometallics 2004, 23, 3727-3732. [CrossRef]

17. Ricci, G.; Boglia, A.; Motta, T. Synthesis of new $\mathrm{Cr}$ (II) complexes with bidentate phosphine ligands and their behavior in the polymerization of butadiene. Influence of the phosphine bite angle on catalyst activity and stereoselectivity. J. Mol. Catal. A Chem. 2007, 267, 102-107. [CrossRef]

18. Ricci, G.; Forni, A.; Boglia, A.; Motta, T.; Zannoni, G.; Canetti, M.; Bertini, F. Synthesis and X-ray Structure of $\mathrm{CoCl}_{2}\left(\mathrm{P}^{i} \mathrm{PrPh}_{2}\right)_{2}$. A New Highly Active and Stereospecific Catalyst for 1,2 Polymerization of Conjugated Dienes When Used in Association with MAO. Macromolecules 2005, 38, 1064-1070. [CrossRef]

19. Ricci, G.; Forni, A.; Boglia, A.; Motta, T. Synthesis, structure, and butadiene polymerization behavior of alkylphosphine cobalt(II) complexes. J. Mol. Catal. A Chem. 2005, 226, 235-241. [CrossRef]

20. Ricci, G.; Forni, A.; Boglia, A.; Sommazzi, A.; Masi, F. Synthesis, structure and butadiene polymerization behavior of $\mathrm{CoCl}_{2}\left(\mathrm{PR}_{\mathrm{x}} \mathrm{Ph}_{3-\mathrm{x}}\right)_{2}(\mathrm{R}=$ methyl, ethyl, propyl, allyl, isopropyl, cyclohexyl; $\mathrm{x}=1,2)$. Influence of the phosphorous ligand on polymerization stereoselectivity. J. Organomet. Chem. 2005, 690, 1845-1854. [CrossRef]

21. Ricci, G.; Motta, T.; Boglia, A.; Alberti, E.; Zetta, L.; Bertini, F.; Arosio, P.; Famulari, A.; Meille, S.V. Synthesis, Characterization, and Crystalline Structure of Syndiotactic 1,2-Polypentadiene: The Trans Polymer. Macromolecules 2005, 38, 8345-8352. [CrossRef]

22. Ricci, G.; Boglia, A.; Motta, T.; Bertini, F.; Boccia, A.C.; Zetta, L.; Alberti, E.; Famulari, A.; Arosio, P.; Meille, S.V. Synthesis and structural characterization of syndiotactic trans-1,2 and cis-1,2 polyhexadienes J. Polym. Sci. Part A Polym. Chem. 2007, 45, 5339-5353. [CrossRef]

23. Ricci, G.; Leone, G.; Boglia, A.; Boccia, A.C.; Zetta, L. cis-1,4-alt-3,4 Polyisoprene: Synthesis and Characterization. Macromolecules 2009, 42, 9263-9267. [CrossRef] 
24. Boccia, A.C.; Leone, G.; Boglia, A.; Ricci, G. Novel stereoregular cis-1,4 and trans-1,2 poly(diene)s: Synthesis, characterization, and mechanistic considerations. Polymer 2013, 54, 3492-3503. [CrossRef]

25. Bansemer, R.L.; Huffman, J.C.; Caulton, K.G. Synthesis and characterization of $\mathrm{VCl}_{3}\left(\mathrm{PMePh}_{2}\right)_{2}$. Inorg. Chem. 1985, 24, 3003-3006. [CrossRef]

26. Holt, D.G.L.; Larkworthy, L.F.; Povey, D.C.; Smith, G.W.; Leigh, G.J. Synthesis and structural studies of complexes of vanadium(II) and vanadium(III) halides with tertiary phosphines. Inorg. Chim. Acta 1993, 207, 11-19. [CrossRef]

27. Bultitude, J.; Larkworthy, L.F.; Povey, D.C.; Smith, G.W.; Dilworth, J.R. The preparation and crystal and molecular structures of trichlorobis(methyldiphenylphosphine)vanadium(III) and its acetonitrile adduct. J. Chem. Soc. Dalton Trans. 1986, 2253-2258. [CrossRef]

28. Nieman, J.; Teuben, J.H.; Huffman, J.C.; Caulton, K.G. Preparation and characterization of monocyclopentadienylvanadium dihalide bis-phosphine complexes-Crystal-structure of (eta-5- $\left.\mathrm{C}_{5} \mathrm{H}_{5}\right) \mathrm{VCl}_{2}\left(\mathrm{PMe}_{3}\right)_{2}$. J. Org. Chem. 1983, 255, 193-204. [CrossRef]

29. Issleib, V.K.; Bohn, V. Phosphin- und Phosphinoxydkomplexe des 3wertigen Vanadins. Z. Anorg. Allg. Chem. 1959, 301, 188-196. [CrossRef]

30. Leone, G.; Pierro, I.; Zanchin, G.; Forni, A.; Bertini, F.; Rapallo, A.; Ricci, G. Vanadium(III)-catalyzed copolymerization of ethylene with norbornene: Microstructure at tetrad level and reactivity ratios. J. Mol. Catal. A Chem. 2016, 424, 220-231. [CrossRef]

31. Ricci, G.; Leone, G.; Sommazzi, A.; Forni, A.; Masi, F. Phosphinic Vanadium Complex, Catalytic System Comprising Said Phosphinic Vanadium Complex and Process for the (co)polymerization of Conjugated Dienes. U.S. Patent Application 20,170,275,312, 18 August 2017.

32. Cotton, F.A.; Lu, J. EPR and Crystallographic Studies of Some Reaction Products of $\mathrm{VCl}_{4}, \mathrm{NbCl}_{4}, \mathrm{and} \mathrm{TaCl}_{4}$ with Trialkyl- and Triarylphosphines. Inorg. Chem. 1995, 34, 2639-2644. [CrossRef]

33. Ernst, R.D.; Freeman, J.W.; Stahl, L.; Wilson, D.R.; Arif, A.M.; Nuber, B.; Ziegler, M.L. Longer but Stronger Bonds: Structures of $\mathrm{PF}_{3}, \mathrm{P}(\mathrm{OEt})_{3}$, and $\mathrm{PMe}_{3}$ Adducts of an Open Titanocene. J. Am. Chem. Soc. 1995, $117,5075-5081$.

34. Zhao, Y.; Truhlar, D.G. The M06 suite of density functionals for main group thermochemistry, thermochemical kinetics, noncovalent interactions, excited states, and transition elements: Two new functionals and systematic testing of four M06-class functionals and 12 other functionals. Theor. Chem. Acc. 2008, 120, $215-241$.

35. Lee, C.; Yang, W.; Parr, R.G. Development of the Colle-Salvetti correlation-energy formula into a functional of the electron density. Phys. Rev. B 1988, 37, 785-789. [CrossRef]

36. Becke, A.D. Density-functional thermochemistry. III. The role of exact exchange. J. Chem. Phys. 1993, 98, 5648-5652. [CrossRef]

37. Vosko, S.H.; Wilk, L.; Nusair, M. Accurate spin-dependent electron liquid correlation energies for local spin density calculations: A critical analysis. Can. J. Phys. 1980, 58, 1200-1211. [CrossRef]

38. Aakeröy, C.B.; Evans, T.A.; Seddon, K.R.; Pálinkó, I. The C-H ‥Cl hydrogen bond: Does it exist? New J. Chem. 1999, 23, 145-152. [CrossRef]

39. Ricci, G.; Sommazzi, A.; Masi, F.; Ricci, M.; Boglia, A.; Leone, G. Well Defined Transition Metal Complexes with Phosphorus and Nitrogen Ligands for 1,3-Dienes Polymerization. Coord. Chem. Rev. 2010, 254, 661-676. [CrossRef]

40. Christman, D.L. Preparation of polyethylene in solution. J. Polym. Sci. Part A1 1972, 10, 471-487. [CrossRef]

41. Gumboldt, V.A.; Helberg, J.; Schleitzer, G. Makromol. Chem. Über die reaktivierung der bei der äuthylen/propylen-copolymerisation verwendeten vanadium-katalysatoren. Macromol. Chem. Phys. 1967, 101, 229-245. [CrossRef]

42. Tait, P.J.T.; Watkins, N.D. Monoalkene Polymerization: Mechanisms in: Comprehensive Polymer Science; Eastmond, G.C., Ledwith, A., Russo, S., Sigwalt, P., Eds.; Pergamon Press Ltd.: Oxford, UK, 1989; Volume 4, Part II; p. 27.

43. Tolman, C.A. Electron donor-acceptor properties of phosphorus ligands. Substituent additivity. J. Am. Chem. Soc. 1970, 92, 2953-2956. [CrossRef]

44. Tolman, C.A. Steric effects of phosphorus ligands in organometallic chemistry and homogeneous catalysis. Chem. Rev. 1977, 77, 313-348. [CrossRef]

45. Bruker. SMART, SAINT and SADABS; Bruker AXS Inc.: Madison, WI, USA, 1997.

46. Sheldrick, G.M. A short history of SHELX. Acta Cryst. 2008, A64, 112-122. [CrossRef] [PubMed] 
47. Sheldrick, G.M. Crystal structure refinement with SHELXL. Acta Cryst. 2015, C71, 3-8.

48. Frisch, M.J.; Trucks, G.W.; Schlegel, H.B.; Scuseria, G.E.; Robb, M.A.; Cheeseman, J.R.; Montgomery, J.A., Jr.; Vreven, T.; Kudin, K.N.; Burant, J.C.; et al. Gaussian 16, Revision A.03; Gaussian, Inc.: Wallingford, CT, USA, 2016. 